\title{
EDUKASI PROGRAM KELUARGA BERENCANA DAN PENGGUNAAN ALAT KONTRASEPSI PADA PUS (PASANGAN USIA SUBUR) DI RW 02 KELURAHAN TANJUNG RIAU BATAM
}

\author{
Yulianti Wulandari ${ }^{1}{ }^{\text {Rachmawaty } M \text { Noer }^{2}, \text { Purwaningsih }^{3} \text {, Rista Sartika Samosir }}{ }^{4}$, Sendy \\ Tonggoria Panjaitan \\ ${ }_{1,2,3,4,5)}$ Program Studi Ilmu Keperawatan, STIKes Awal Bros Batam \\ e-mail: wlndr_ylnt@yahoo.com
}

\begin{abstract}
Abstrak
Pendahuluan Program Keluarga Berencana adalah merupakan program pemerintah guna meningkatan kepedulian dan peran serta masyarakat melalui kedewasaan usia perkawinan, pengaturan usia kelahiran anak, pembinaan ketahanan dalam keluarga, peningkatan kesejahteraan dalam keluarga kecil yang bahagia dan sejahtera. Penggunaan alat kontrasepsi merupakan hal yang belum diminati oleh masyarakat, Penyebabnya karena masyarakat masih merasa takut memakai alat kontrasepsi dan juga kurangnya pengetahuan tentang alat kontrasepsi. Tujuan dari pengabdian masyarakat ini untuk mengedukasi Pasangan Usia Subur di RW 02 kelurahan Tanjung Riau, Hasil Pengabdian ini di harapkan semua pasangan usia subur di RW 2 Kelurahan Tanjung Riau dapat memahami tentang Program Keluarga Berencana serta pentingnya penggunaan alat kontrasepsi.
\end{abstract}

Kata kunci: Pendidikan kesehatan, Pengetahuan Pasangan usia subur, Alat Kontrasepsi

\begin{abstract}
The introduction of family planning Program is a government program to improve awareness and community participation through the maturity of marital age, child birth age arrangement, endurance coaching in the family, improving welfare in a happy and prosperous small family. The use of contraceptives is a thing that has not been enthused by the community, the cause because people still feel afraid to use contraceptives and also lack of knowledge about contraceptives. The purpose of this community devotion to educate the family of childbearing age in RW 02 Kelurahan Tanjung Riau, the result of the devotion is expected all the fertile age couples in the RW 2 Kelurahan Tanjung Riau can understand about the family planning Program as well as the importance of the use of contraceptives.
\end{abstract}

Keywords: Health Education, Knowledge pair of the couples age fertile, Contraceptive Implants

\section{PENDAHULUAN}

Indonesia merupakan negara yang sangat berkembang pesat dalam pertambahan jumlah penduduk, dimana memiliki jumlah penduduk terbesar keempat setelah negara China, India, dan Amerika Serikat. Menurut Sulistyawati (2011), masalah kependudukan yang dihadapi Indonesia saat ini tidak hanya jumlah penduduk besar dengan laju pertumbuhan penduduk yang relatif tinggi, tetapi juga penyebaran penduduk yang merata, struktur umur serta kualitas penduduk yang masih rendah.

Pemerintah saat ini sedang mengupayakan penanggulangan laju pertumbuhan penduduk Upaya yang di lakukan pemerintah dalam menanggulangi masalah laju pertumbuhan penduduk yaitu dengan mengeluarkan kebijakan program keluarga berencana (KB) yang berguna untuk membangun pertumbuhan ekonomi yang lebih baik serta mampu menciptakan keluarga yang berkualitas dan sejahtera dengan tingkat kelahiran dapat terkendali (Syaifudin , 2013).

Program Keluarga Berencana ( KB ) adalah suatu program yang dicanangkan pemerintah dalam upaya peningkatan kepedulian dan peran serta masyarakat melalui pendewasaan usia perkawinan (PUP ), pengaturan kelahiran, pembinaan ketahanan keluarga, peningkatan kesejahteraan keluarga 
kecil, bahagia dan sejahtera (Hanafi, 2010).

Untuk mensukseskan program keluarga berencana Pemerintah menawarkan macam-macam alat kontrasepsi yang dapat di gunakan oleh masyarakat. Macam-macam alat kontrasepsi, antara lain intra uterine device (IUD), metode operatif wanita (MOW), metode operatif pria (MOP), kondom, implan, suntik dan pil. Dari semua alat kontrasepsi ini, semuanya memiliki keunggulan masingmasing.

Secara nasional jumlah peserta KB tercatat sebanyak 31.640 .957 peserta dan jumlah pasangan usia subur (PUS) terhitung sebanyak 44.431.227 pasangan, sehingga keikutsertaan KB dari seluruh (PUS) sebesar 71,21\% (Endang, 2012). Berdasarkan data dari BKKBN KEPRI, jumlah PUS adalah 440.488, dengan jumlah pengguna KB aktif 237.918 jiwa. Dari data tersebut menunjukan bahwa dari masyarakat luas yang ada di Indonesia banyak yang belum mengikuti program keluarga berencana $(\mathrm{KB})$.

Sebagai tenaga medis, edukasi dini terkait dengan Program KB dan Penggunaan Alat Kontrasepsi ini harus kita perkenalkan oleh pasangan usia subur sehingga dapat memberkan pengetahuan serta membantu pemerintah dalam menjalankan program Keluarga Berencana serta Penggunaan Alat Kontrasepsi yang aman untuk mengendalikan jumlah kelahiran di indonesia. Kegiatan ini dilaksanakan di Ruang pertemuan warga Tanjung Riau.

\section{METODE}

Adapun sasaran dalam kegiatan pengabdian masyarakat ini adalah pasangan usia subur di RW 2 Tanjung Riau Batam. Metode yang digunakan dalam kegiatan penyuluhan dilakukan dengan tiga macam, yaitu : metode ceramah, diskusi dan tanya jawab. Kegiatan ini di awali dengan pengisian kuesioner tentang pengenalan program KB dan Kontrasepsi pada pasangan usia subur. Dilanjutkan pemaparan tentang Program Keluarga Berencana dan di lanjutkan dengan Pengenalan terhadap Kontrasepsi dan jenis- jenis penggunaan kontrasepsi aman untuk pasangan usia subur. Hasil akhir dari edukasi kegiatan pengabdian masyarakat ini adalah memberikan post tes kepada pasangan usia subur sebagai bahan evaluasi kegiatan pengabdian masyarakat ini.

\section{HASIL DAN PEMBAHASAN}

Pelaksanaan kegiatan ini dilakukan pada hari Sabtu, tanggal 10 Januari 2020. Adapun prosedur yang dilakukan pada pengabdian masyarakat di RW 02 Tanjung Riau Batam adalah : 1) Memberikan pre tes pada pasangan usia subur tentang Program KB dan Kontrasepsi 2) Memberikan edukasi serta paparan materi tentang Program KB dan Penggunaan alat kontrasepsi aman bagi pasangan usia subur di RW 02 Tanjung Riau Batam 3) Pembukaan sesi tanya jawab bagi pasangan usia subur 4) Mengadakan Post Tes sebagai evaluasi bahan edukasi pengabdian masyarakat pada pasangan usia subur di RW 02 Tanjung Riau Batam terhadap Program Keluarga Berencana dan Penggunaan Alat Kontrasepsi yang aman. Pasangan usia subur di wilayah tersebut sangat senang dengan kegiatan pengabdian masyarakat yang melibatkan mereka karena dapat menambah wawasan baru.

\section{SIMPULAN}

1. Pengetahuan pasangan usia subur tentang program KB dan alat kontrasepsi sebelum diberikan pendidikan kesehatan sebagian besar memiliki pengetahuankurang.

2 Pengetahuan pasangan usia subur tentang Program KB dan alat kontrasepsi sesudah diberikan pendidikan kesehatan sebagian besar memiliki pengetahuan baik.

3. Ada pengaruh pendidikan kesehatan terhadap pengetahuan pasangan usia subur tentang Program KB dan alat kontrasepsi. 


\section{SARAN} berikut:

Beberapa saran yang dapat disampaikan dari kegiatan pengabdian masyarakat ini adalah sebagai

1. Kedapan harus dilakukan observasi tinjau ulang untuk pengetahuan PUS

2. Berikutnya Pengenalan lebih dalam tentang materi kontrasepsi

\section{UCAPAN TERIMA KASIH}

Ucapan terimakasih penulis sampaikan kepada Bapak Camat Sekupang serta Puskesmas Sekupang dan warga RW 02 Kelurahan Tanjung Riau Sekupang Batam dalam kegiatan Pengabmas ini sehingga dapat terlaksana dengan baik.

\section{DAFTAR PUSTAKA}

Puskesmas, Tanjung riau Sekupang. (2019).

Endang, E. (2012). Pengaruh pendidikan kesehatan tentang kontrasepsi pria terhadap motivasi pria pus menjadi akseptor kb vasektomi di wilayah kerja puskesmas pauh padang.

:http://repository.unand.ac.id/18630/1/rep ository.docx

Sulistyawati, Ari. (2011). Pelayanan keluarga berencana. Jakarta : Salemba Medika.

Setiadi. (2012). Konsep dan penulisan riset keperawatan. Yogyakarta. Graha Ilmu.

Fitriani,S. (2011). Promosi Kesehatan. Yogyakarta : Graha Ilmu. 